\title{
Micro-Autoradiographic Studies on Host-Parasite Interactions
}

\author{
I. The Infection of Phaseolus vulgaris with Tritium Labeled Uredospores \\ of Uromyces phaseoli
}

\author{
K. MENDGEN and R. HEITEFUSS
}

Institut für Pflanzenpathologie und Pflanzenschutz der Universität Göttingen

Received July 7, 1975

\begin{abstract}
Tritium labeled uredospores of Uromyces phaseoli were produced be feeding the host, Phaseolus vulgaris, with ${ }^{3} \mathrm{H}$-orotic acid. These spores were allowed to germinate on and to penetrate into a bean leaf. 24 hrs after inoculation, the bean rust had formed the first haustorium. All fungal structures, including the fungus walls, were heavily labeled. No label could be detected in the cells that had come into contact with the hyphae. In the infected host cell, the haustorium was
\end{abstract}

labeled heavily, but the sheath around the haustorium and the host cell remained free of label. These results indicate that no detectable amounts of label leach from the bean rust into the host at this stage of infection although it is known that the rust takes up many metabolites. Since the sheath remains free of label and all fungal structures are evenly labeled, it is concluded that the sheath is formed by the host.

Key words: Bean - Rust - Haustorium - Sheath - Autoradiography - Infection - Electron microscopy - Phaseolus vulgaris - Uromyces phaseoli.

Cytological studies with the light- and electron-microscope have provided much detailed information on structural features at different stages of the infection process in many host-parasite combinations ( $c f$. Bracker and Littlefield, 1973; Bushnell, 1972; and many others). However, knowledge about the functional roles of the observed structures is very meager. The question, whether an exchange of metabolites occurs between host and parasite and at which site it takes place has been answered only to a very limited extend. The parasite takes up different metabolites from the host. This was demonstrated by feeding radioactive compounds to the host plant and the subsequent analysis of fungal spores or hyphae with biochemical methods (Reisener et al., 1970; Mount and Ellingboe, 1969; Slesinski and Ellingboe, 1971). Cytological studies have shown that labeled metabolites accumulate at the site of infection (Shaw, 1967) and are taken up by the parasite. Puccinia graminis tritici accumulates ${ }^{3} \mathrm{H}$-uridine, ${ }^{3} \mathrm{H}$-cytidine, ${ }^{3} \mathrm{H}$-leucine (Bhattacharya and Shaw, 1967) and ${ }^{14} \mathrm{C}$-orotic acid (Heitefuss, 1970) in mycelium and uredospores. Uromyces phaseoli incorporates ${ }^{14} \mathrm{C}$-orotic acid, ${ }^{3} \mathrm{H}$-uridine and ${ }^{3} \mathrm{H}$-glycine after feeding these compounds to leaves of the host, Phaseolus vulgaris (Staples and Ledbetter, 1958; Fuchs and Tschen, 1969; Favali and Marte, 1973). Different results were obtained in studies of ${ }^{3} \mathrm{H}$-cytidine uptake by Puccinia recondita (Nielsen and Rohringer, 1963) and ${ }^{3} \mathrm{H}$-thymidine uptake by
Uromyces phaseoli (Staples and Ledbetter, 1960). The transport of nucleosides into the parasite seems to start with the formation of the first haustorium of Puccinia coronata in oat leaves (Onoe et al., 1973).

In order to characterize the interactions between host and parasite it is also important to know whether and at which stage after infection the parasite releases substances into the host. Fungal products may be toxins, enzymes involved in pathogenesis or compounds metabolized by the host without further consequences. Moreover, secreted compounds could serve as a "message" of the parasite. Autoradiography could help to show whether and where it could be received by the host. However, only few investigators attempted to follow the transport of labeled substances from the parasite to the host. Jones (1966) inoculated oat leaves with ${ }^{35} \mathrm{~S}$ labeled uredospores of Puccinia coronata. Autoradiographic analyses at the flecking stage demonstrated that ${ }^{35} \mathrm{~S}$ was released from the spores, absorbed by the host tissue and transported to the developing second leaves and roots. Ehrlich and Ehrlich (1970) used ${ }^{14} \mathrm{C}$ labeled uredospores of Puccinia graminis tritici and showed by means of electron microscope autoradiograms prepared from tissue at 5 days after inoculation, that passage of radioactivity had occurred from the parasite to the host. Both these investigations were carried out at rather late stages after inoculation when degeneration of infected cells had started. Therefore, information 

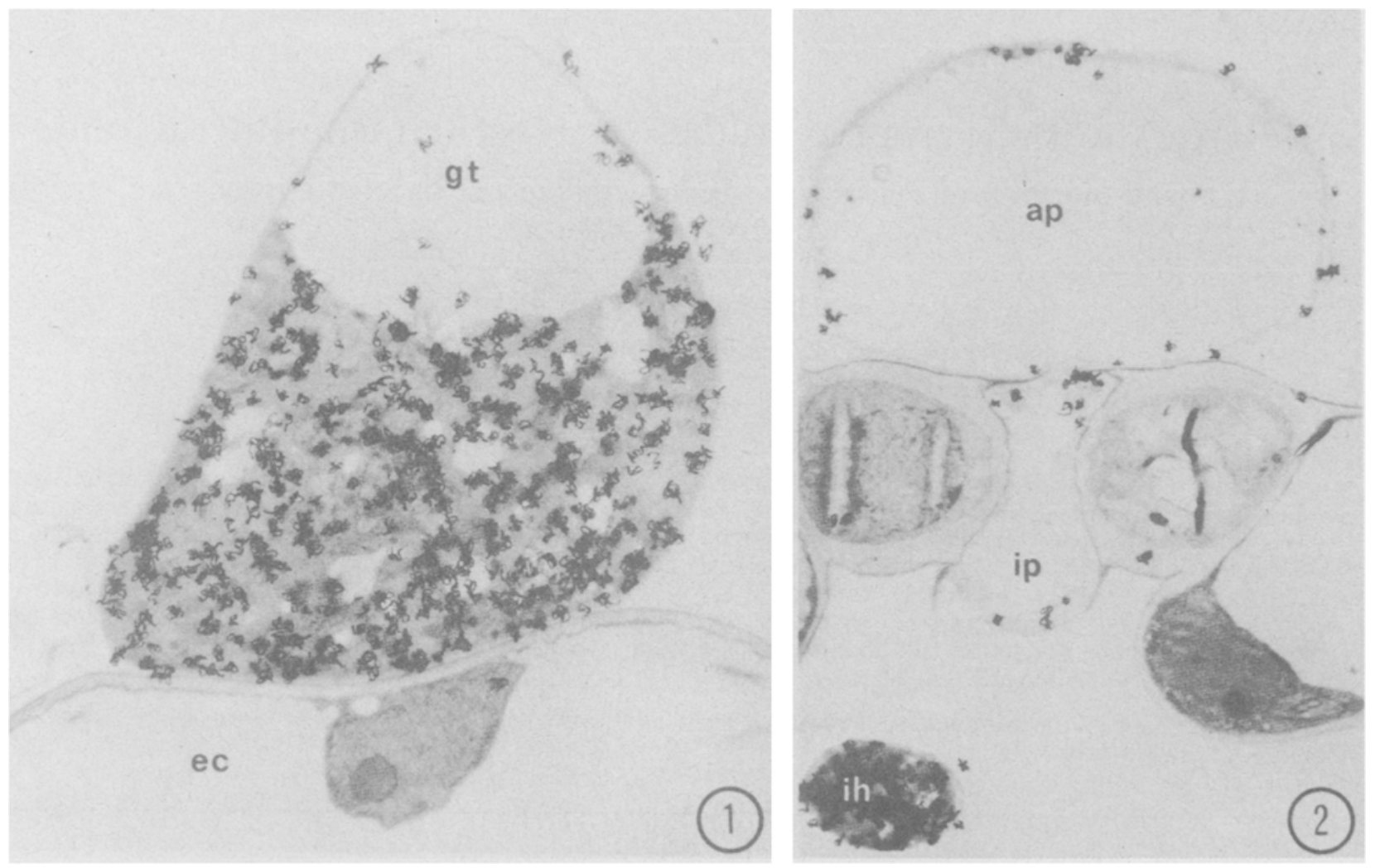

Fig. 1. Cross section of the bean rust germ tube $(g t)$ growing on an epidermal cell $(e c)$. The germ tube is heavily labeled whereas the epidermal cell is not $(\times 4900)$

Fig. 2. Over the stoma, the germ tube differentiates into the appressorium $(a p)$ and penetrates with the infection peg (ip) into the substomatal chamber and forms the substomatal vesicle and the infection hypha subsequently. In this figure, the cytoplasm has passed into the infection hypha $(i h)$. All fungal structures are labeled $(\times 2300)$

is necessary on a possible release of fungal substances very early during pathogenesis, since the decisive events determining compatibility or incompatibility are assumed to occur at such early stages.

We applied electron microscope autoradiography with ${ }^{3} \mathrm{H}$ labeled compounds to get a high resolving power. ${ }^{3} \mathrm{H}$-orotic acid was used because it is taken up intensively by Uromyces phaseoli and highly labeled uredospores can be prepared in the compatible combination. Orotic acid was also selected because it is incorporated to a great extent into nucleic acids, which might be important during early stages of the host-parasite interactions (Heitefuss, 1966).

\section{Materials and Methods}

Bean plants (Phaseolus vulgaris, cv. Favorit) were grown in compost soil at $21^{\circ} \mathrm{C}$ under approximately $4000 \mathrm{~lx}$ incandescent light for $16 \mathrm{hrs} /$ day. Ten days after planting, primary leaves were inoculated with a water-washed spore suspension of Uromyces phaseoli (Pers.) Wint. var. typica Arth. and kept under high humidity conditions during $24 \mathrm{hrs}$. Four days later, a small portion of the leaf was cut from the inoculated area and immersed with the petiole in $7 \mathrm{ml}$ destilled water containing $200 \mu \mathrm{Ci}\left(5{ }^{3} \mathrm{H}\right)$-orotic acid (specific activity $29 \mathrm{Ci}$ /
$\mathrm{mM}$, Amersham Buchler). After 6 days, when the isotope solution was taken up by the leaf portion, the spores developed on the leaf were harvested. These labeled spores were washed for $1 \mathrm{hr}$ in tap water and put on a primary leaf of a 10-day-old bean plant. $24 \mathrm{hrs}$ later, pieces of $1 / 2 \times 2 \mathrm{~mm}$ leaf tissue were cut and fixed for $12 \mathrm{hrs}$ in $3.5 \%$ glutaraldehyde in $0.08 \mathrm{M}$ cacodylate buffer $\mathrm{pH} 7.1$. After washing in buffer and postosmication, the material was washed again and dehydrated in graded ethanol series. The $96 \%$ ethanol contained $1 \%$ uranylacetate in which the material was left at $60^{\circ} \mathrm{C}$ over night. After treatment with propylene oxide and embedment in low viscosity epoxy resin (Spurr, 1969), golden coloured sections were cut with a Reichert OM UIII ultramicrotome and mounted on copper grids. The sections were stained with lead citrate and coated with a carbon film. The Ilford L 4 photoemulsion was applied as a gelled monogranular layer following the method of Caro and van Tubergen (1962). The grids were exposed for about five months at $4^{\circ} \mathrm{C}$ over silica gel and developed after gold latensification in Photo-Rex-Ascorbic acid developer prepared according to Salpeter and Szabo (1972). The sections were examined in a Philips EM 301 and in a Zeiss EM 10A electron microscope operating at 80 and $100 \mathrm{KV}$.

\section{Results}

The ultrastructure of the infection process of Uromyces phaseoli in a susceptible bean was studied earlier 

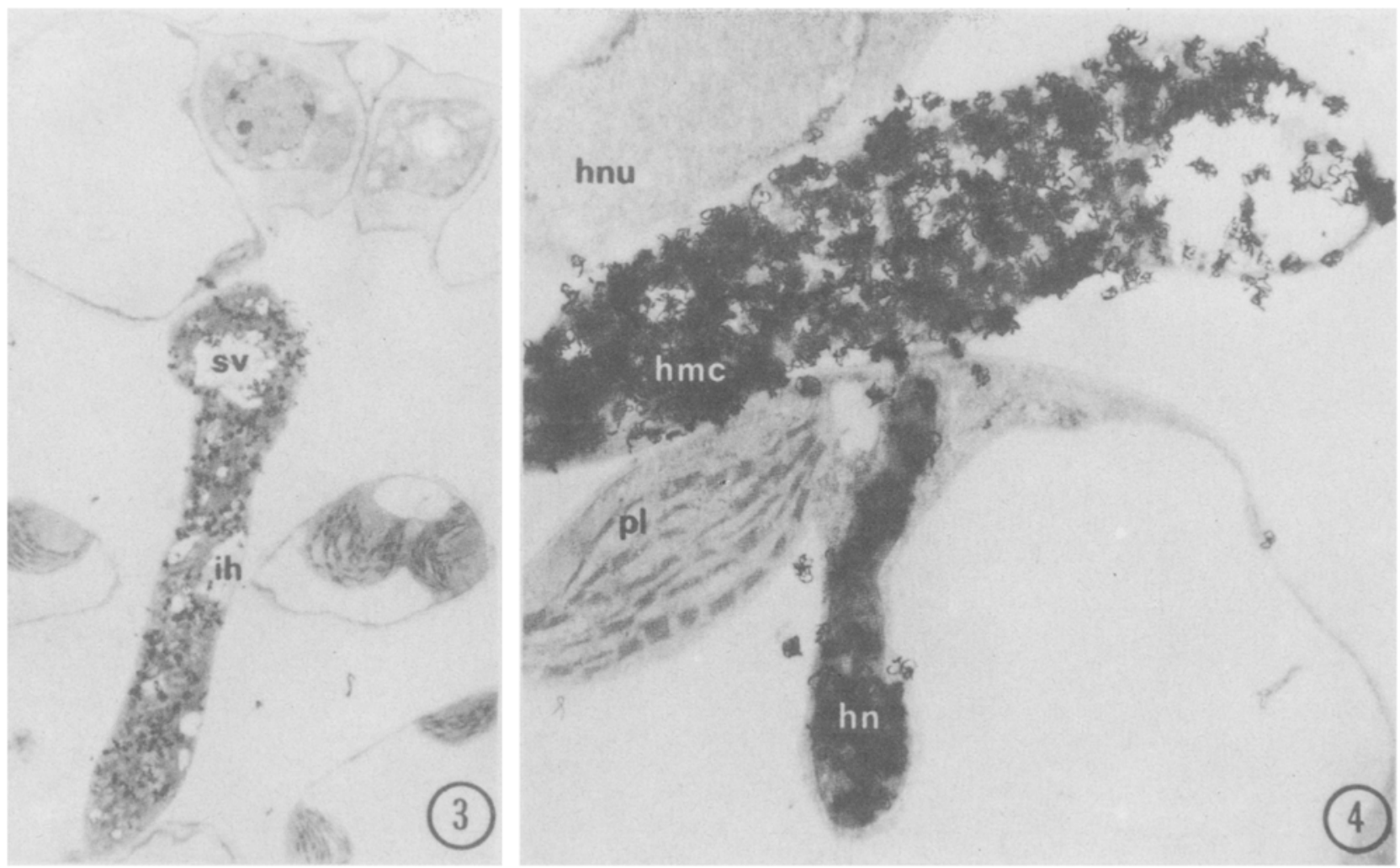

Fig. 3. Substomatal vesicle $(s v)$ and infection hypha $(i h)$ of the fungus in the leaf $(\times 1720)$

Fig. 4. At the tip of the infection hypha, the haustorial mother cell $(h m c)$ penetrates into the host cell and forms there the haustorial neck $(h n)$ and later the haustorium. The fungus is labeled, the host cytoplasm ( $p l$ plastids, hnu host nucleus) remains unlabeled $(\times 7300)$

by Mendgen (1973). By using the same cultivar and the same incubation conditions, we obtained a time course of the early phases of infection (Mendgen, unpublished): After uredospore germination and formation of the appressorium, the infection peg penetrates the stoma around $12 \mathrm{hrs}$ after placing the spores on the leaf surface. In the substomatal cavity, the substomatal vesicle develops, elongates and at the tip of the infection hypha, the haustorial mother cell forms the first haustorium about $6 \mathrm{hrs}$ later. Therefore, at about $24 \mathrm{hrs}$ after inoculation, haustoria described in this paper were about 3-6 hrs old. At this stage, the cytoplasmic content had disappeared from the spores. Only in some cases, cytoplasm was still present in the germ tube. In all the further developed infections, the appressorium and even the infection peg were empty and most of the cytoplasm was found in the intracellular hypha (infection hypha) and in the haustorium. The distribution of radioactivity followed a similar pattern.

Fig. 1 shows an epidermal cell with a uniformly tritium labeled germ tube which emerged from a radioactive uredospore. No radioactive material which might have diffused from the germ tube into the epi- dermal cells was detectable since the host showed no label above normal background.

In an empty appressorium and in the empty infection peg (Fig. 2) - the cytoplasm had passed into the infection hypha and into the first haustorium at this stage of infection-, silver grains were observed regularly on the fungal wall. The number of silver grains on the stomatal cells appeared somewhat higher ( 0.8 grains $\left./ 100 \mu^{2}\right)$ than the background level $(0.35$ grains $/ 100 \mu^{2}$ ). However, we could not prove this exactly since the number of empty appressoria observed were not numerous enough for statistical evaluation of the data.

The substomatal vesicle and the infection hypha in the leaf mesophyll were labeled uniformly like the germ tube (Fig.3). The infection hypha contained numerous nuclei (Fig.5). Compared with the fungal cytoplasm, neither nuclei nor mitochondria of the bean rust seemed to contain a higher amount of radioactive material. In the mesophyll cells of the bean that were in contact with the fungus, no obvious label was observed.

Also the haustorial mother cell which penetrates with its penetration peg into the host cell (Fig.4) was 

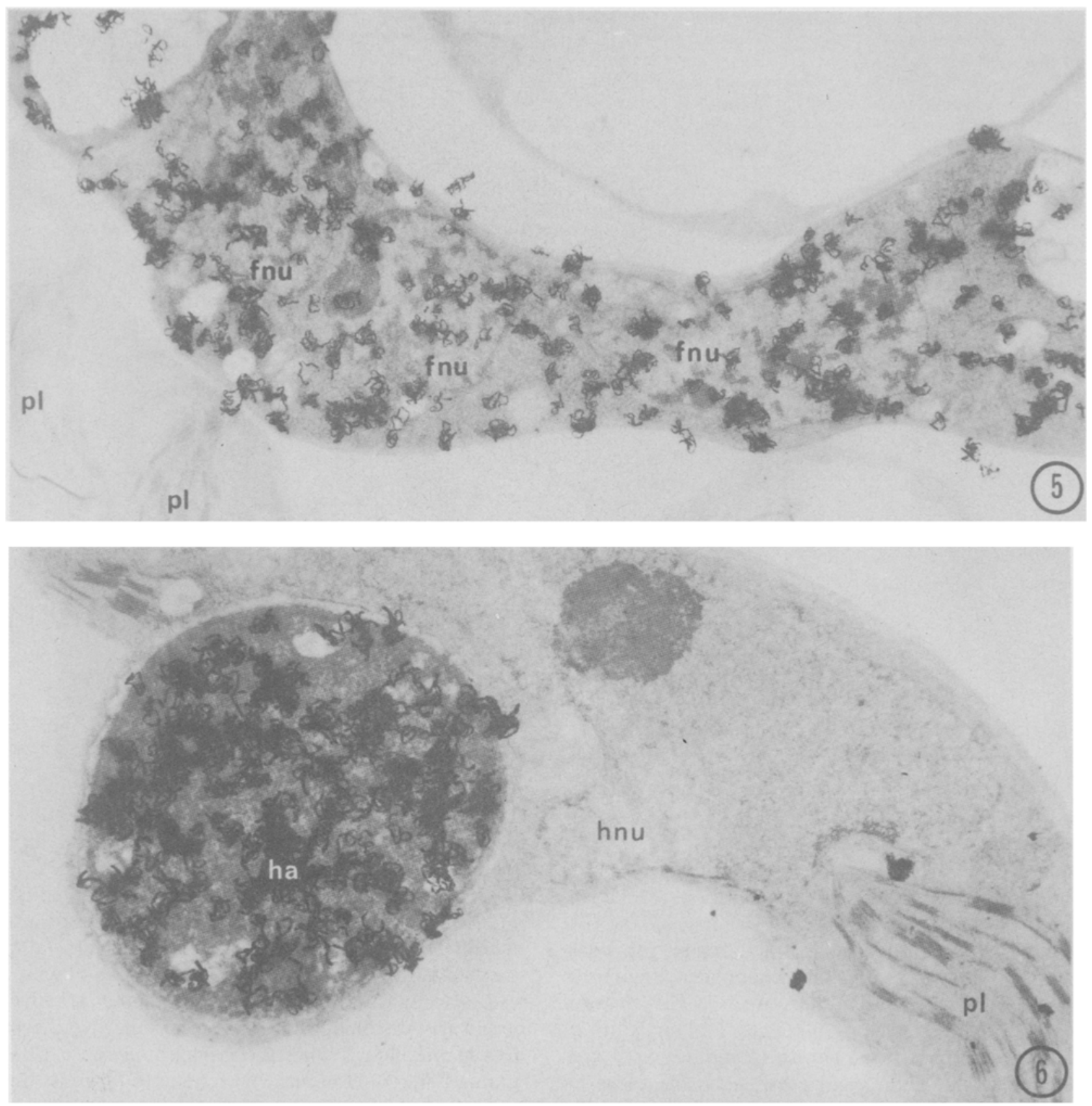

Fig. 5. The label is distributed evenly over all organelles ( $f n u$ fungal nucleus) of the fungal cytoplasm $(\times 7400)$

Fig. 6. The first haustorium of the bean rust $(h a)$ is heavily labeled. The nucleus of the host cell (hnu) has migrated close by the haustorium. But no label seems to have diffused from the haustorium (ha) in any of the host organelles $(\times 11200)$

labeled heavily (more than 250 grains $/ 100 \mu^{2}$ ). There was no obvious label in the infected cell. We do not know, however, whether some sporadic grains in the host cell (grain density 0.8 grains $/ 100 \mu^{2}$ ) represent radioactive substances diffused from the fungus into the infected cells or whether this is mainly background activity.
The fully developed first haustorium in the host cell is shown in Figs. 6 and 7. The nucleus, lying close to the haustorium, was surrounded by a layer of cytoplasm larger than the amount of cytoplasm normally found along the cell wall. The haustorium was labeled uniformly $\left(190\right.$ grains $\left./ 100 \mu^{2}\right)$, but with no label on the sheath (Fig.7). No radioactivity was detected in 


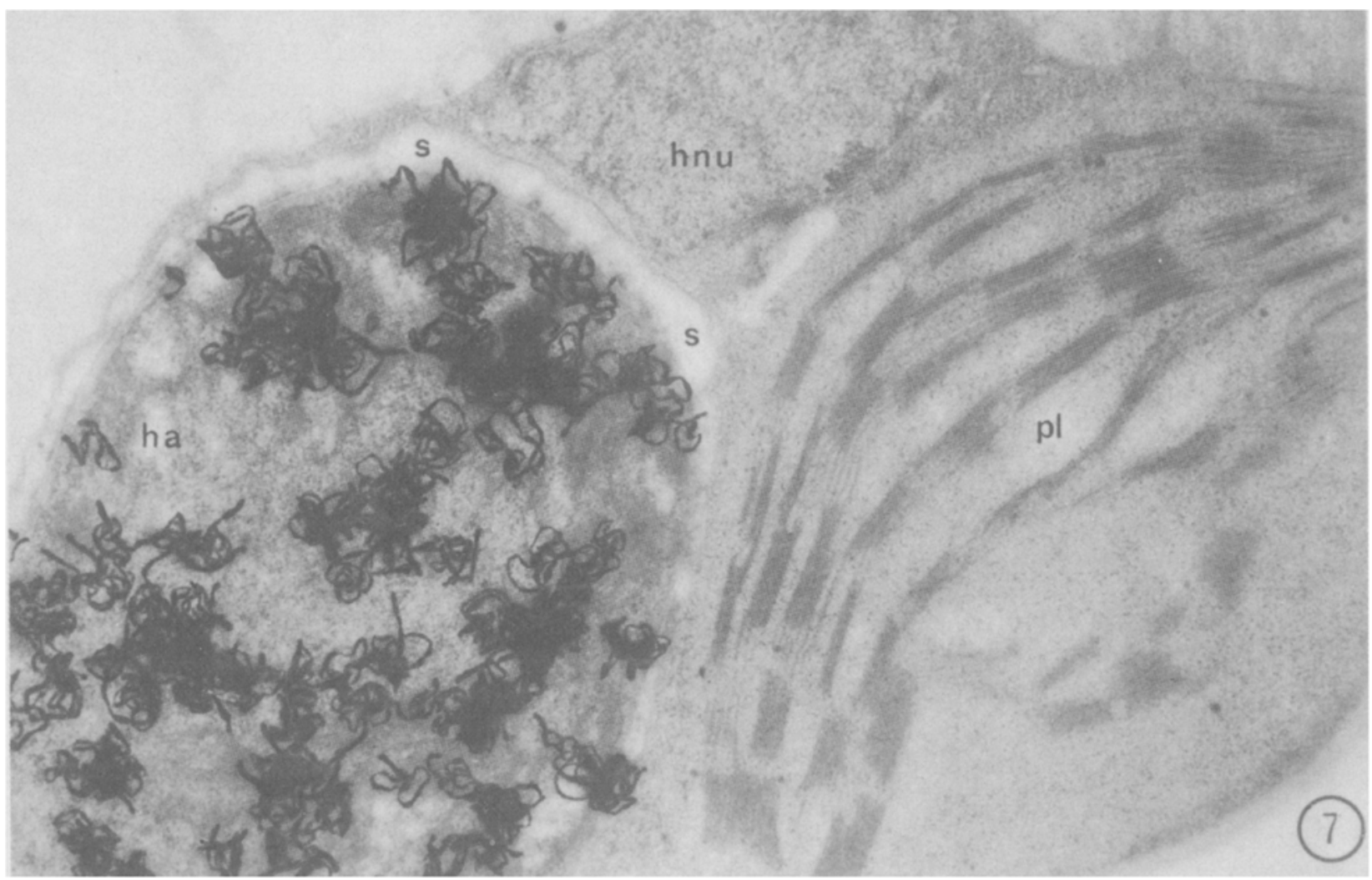

Fig. 7. In the host cell, the haustorium (ha), but not the sheath $(s)$ of the haustorium is labeled. No label can be seen over the host nucleus $(h n u)$ or the plastid $(p l)(\times 21000)$

the cytoplasm or in any organelle of the infected host cell.

\section{Discussion}

The water soluble orotic acid and its low molecular weight metabolites may have been lost to a certain extent during preparation of the specimen, since glutaraldehyde fixes most of the polymeric substances in the cell, whereas many unbound small molecules may leach out during fixation and the subsequent washing in buffer. It is known, that glutaraldehyde binds only $25-65 \%$ of the free amino acids like leucine present in the tissue (Peters and Ashley, 1967). For orotic acid and its metabolites similar or even lower values might be expected. Therefore, radioactivity demonstrated in this study mainly seems to indicate labeled macromolecules. Orotic acid is known to be an effective precursor of pyrimidine-nucleotides and RNA in bean leaves (Ross, 1965). After feeding labeled orotic acid, radioactivity is incorporated extensively into nuclei of the host and into fungal structures (Fuchs and Tschen, 1969; Heitefuss, 1970). In our experiments, part of the ${ }^{3} \mathrm{H}$-orotic acid supplied to the plant may have been taken up as such by the fungus and incorporated there into the RNA of nucleus and ribosomes. However, metabolisation of the original compound, turnover of the labeled nucleic acids and isotope exchange of ${ }^{3} \mathrm{H}$ during its way into the spores and during spore germination can not be excluded. The general distribution of radioactivity in the fungus including the walls and the lack of any accumulation in the nucleus indicates that other compounds besides nucleic acids were labeled.

Before the spores were applicated on to the leaf, they were washed in water since uredospores release large amounts of substances during the first $10 \mathrm{~min}$ after being in contact with water (Daly et al., 1967). This was also necessary in order to remove the selfinhibitor and it allows very dense infections which are needed for electron microscopy.

After this treatment, the epidermal cells remained free of radioactivity although spores and germ tubes were heavily labeled. When the fungus contacted the leaf mesophyll cells or when it established an haustorium within the cell, again no indication of label in the host could be found indicating a transfer of label from the parasite to the host.

However, the present study can not exclude completely a release of small molecules from the parasite to the host since the technique applied can detect 
only substances that are incorporated into polymers of the cytoplasm. But the high activity in the haustorium (sometimes far more than 250 grains $/ 100 \mu^{2}$ ) and the low background which seemed only slightly increased in the cytoplasm of the infected cell (from 0.35 grains $/ 100 \mu^{2}$ background to 0.8 grains $/ 100 \mu^{2}$ host cytoplasm) indicates, that the parasite's release of small molecules which are incorporated into high molecular material of the host, or a release of high molecular material into the host, must be relatively low, if it exists at all. Starting from the grain densities over the haustorium and over the host cytoplasm, we estimate, that the amount of substances released from the parasite and incorporated into the host can not account for more than $1 \%$ of the parasite's dry mass.

Our results seem to be in contrast to the micrographs of Ehrlich and Ehrlich (1970), who demonstrate a passage of radioactivity from the pathogen to the host. But in their study, ${ }^{14} \mathrm{CO}_{2}$ was used and the leaves were harvested and fixed 5 days after incoulation of the leaf. During this time, necrosis of some cells and haustoria begins (see Bracker and Littlefield, 1973) and unspecific diffusion may occur. Moreover, ${ }^{14} \mathrm{CO}_{2}$, secreted by the fungus may be refixed by the plant. The same holds for the studies of Jones (1966) who emphasizes, however, that although he observed a diffusion of ${ }^{35} \mathrm{SO}_{4}$ from the parasite to the host, the bulk of radioisotope is retained in the fungus. $\mathrm{He}$ detected the radioactivity still in uredospores arising from the sori that were produced from the labeled spores. We doubt that an aegricorpus that is some days old can be compared with the early infection stages when haustoria are about 3-6 hrs old only.

In the present study, no transfer of tritium labeled high molecular weight substances, possibly nucleic acids, from parasite to host could be demonstrated. Leaching of small molecules during processing, however, could not be avoided. Therefore more information might be obtained by feeding the parasite with labeled amino acids since they seem to be fixed much better with glutaraldehyde. Another improvement would be if processing could be performed in water free media to prevent any leaching. Furthermore it remains open whether older haustoria release substances into the host somewhat later during pathogenesis and whether differences occur between compatible and incompatible combinations.

The labeled uredospores produce completely labeled fungal structures, including the walls. However, the clearly detectable sheath around the haustorium within the infected host cell shows no radioactivity that indicates an incorporation of material from the parasite.

This result brings new light on the nature of the sheath synthesis. A number of speculations have been made about the origin of the haustorial sheath (Bracker and Littlefield, 1973). The sheath, surrounded by the extrahaustorial membrane, Golgi bodies and endoplasmic reticulum, represents the most obvious interphase between host and parasite. The Golgi bodies are assumed to secret substances into the sheath. Around the bean rust haustorium, these secretory vesicles contain peroxidase activity (Mendgen, 1975). In older haustoria, the peroxidase activity can be detected in the sheath (Mendgen and Fuchs, 1973). However, it remained open if only the host contributes to the sheath material or both, host and parasite. Autoradiographic studies during sheath formation (Manocha and Lee, 1972) of the fungus Choanephora cucurbitarum infected with Piptocephalis virginiana indicate that the sheat around haustoria is formed by the host. The sheath formed in mycoparasitism and the sheath formed in rust parasitism must differ, however, since the sheath around haustoria of $P$. virginiana is at last partly composed of chitin and there is no evidence for chitin in the case of rust haustoria. Our results with Uromyces phaseoli show that the sheath does not contain radioactivity although the fungal structures, including the fungal walls, are uniformly labeled. This observation suggests that the sheath around the haustorium of rusts is formed by the host only.

Acknowledgements. We thank Prof. Dr. F. Mayer for the permission to use the Philips electron microscope. Appreciation is expressed to the Deutsche Forschungsgemeinschaft for financial support ( $\mathrm{Me} 523 / 2)$.

\section{References}

Bhattacharya, P. K., Shaw, M.: The physiology of hostparasite relations. XVIII. Distribution of tritium-labelled cytidine, uridine and leucine in wheat leaves infected with the stem rust fungus. Canad. J. Bot. 45, 555- 563 (1967)

Bracker, C. E., Littlefield, L. J.: Structural concepts of hostpathogen interfaces. In: Fungal pathogenicity and the plant's response, J. W. Byrde, C. V. Cutting, eds. London: Academic Press 1973

Bushnell, W. R.: Physiology of fungal haustoria. Ann. Rev. Phytopath. 10, $151-176(1972)$

Caro, L. G., van Tubergen, R. P.: High resolution autoradiography. I. Methods. J. Cell Biol. 15, 173-188 (1962)

Daly, J. M., Knoche, H. W., Wiese, M. V.: Carbohydrate and lipid metabolism during germination of uredospores of Puccinia graminis tritici. Plant Physiol. 42, 1633-1642 (1967)

Ehrlich, M. A., Ehrlich, H. G.: Electron microscope autoradiography of ${ }^{14} \mathrm{C}$ transfer from rust uredospores to wheat host cells. Phytopathology 60, 1850-1851 (1970)

Favali, M. A., Marte, M.: Electron microscope-autoradiography of rust-affected bean leaves labelled with tritiated glycine. Phytopath. Z. 76, 343-347 (1973)

Fuchs, W. H., Tschen, J.: Syntheseaktivität und Größe der Zellkerne von Phaseolus vulgaris nach Infektion mit Uromyces phaseoli typica. Neth. J. P1. Path. 75, 86-95 (1969)

Heitefuss, R.: Nucleic acid metabolism in obligate parasitism. Ann. Rev. Phytopath. 4, $221-244$ (1966) 
Heitefuss, R.: Der Einfluß von Actinomycin auf Puccinia graminis tritici auf Weizen und den Einbau von Orotsäure- $\mathrm{C}^{14}$ und Uridin- $\mathrm{H}^{3}$ in Wirtspflanze und Parasit. Phytopath. Z. 69, 107-114 (1970)

Jones, J. P.: Absorption and translocation of $\mathrm{S}^{35}$ in oat plants inoculated with labeled crown rust uredospores. Phytopathology 56, 272-275 (1966)

Manocha, M. S., Lee, K. Y.: Host-parasite relations in mycoparasite. II. Incorporation of tritiated $\mathrm{N}$-acetyl-glucosamine into Choanephora cucurbitarum infected with Piptocephalis virginiana. Canad. J. Bot. 50, 35-37 (1972)

Mendgen, K.: Feinbau der Infektionsstrukturen von Uromyces phaseoli. Phytopath. Z. 78, 109-120 (1973)

Mendgen, K.: Ultrastructural demonstration of different peroxidase activities during the bean rust infection process. Physiol. Plant Path. 6, 275-282 (1975)

Mendgen, K., Fuchs, W. H.: Elektronenmikroskopische Darstellung peroxydatischer Aktivitäten bei Phaseolus vulgaris nach Infektion mit Uromyces phaseoli typica. Arch. Mikrobiol. 88, 181-192 (1973)

Mount, M. S., Elligboe, A. H.: ${ }^{32} \mathrm{P}$ and ${ }^{35} \mathrm{~S}$ transfer from susceptible wheat to Erysiphe graminis f.sp. tritici during primary infection. Phytopathology 59, 235 (1969)

Nielsen, J., Rohringer, R.: Incorporation of cytidine- $\mathrm{H}^{3}$ into the primary leaf of wheat following infection with Puccinia recondita Rob. ex. Desm. Canad. J. Bot. 41, 1501-1508 (1963)

Onoe, T., Tani, T., Naito, N.: The uptake of labeled nucleosides by Puccinia coronata grown in susceptible oat leaves. Rept. Tottori Mycol. Inst. (Japan) 10, 303-312 (1973)

Dr. Kurt Mendgen, Prof. Dr. Rudolf Heitefuss

Institut für Pflanzenpathologie und Pflanzenschutz der Universität D-3400 Göttingen, Grisebachstr. 6, Federal Republic of Germany
Peters, Th., Ashley, Ch. E.: An artifact in radioautography due to binding of free amino acids to tissues by fixatives. J. Cell Biol. 33, 53-60 (1967)

Reisener, H. J., Ziegler, E., Prinzing, A.: Zum Stoffwechsel des Mycels von Puccinia graminis var. tritici auf der Weizenpflanze. Planata (Berl.) 92, 355-357 (1970)

Ross, C.: Comparison of incorporation and metabolism of RNA pyrimidine nucleotide precursors in leaf tissues. Plant Physiol. 40, 65-73 (1965)

Salpeter, M. M., Szabo, M.: Sensitivity in electron microscope autoradiography. I. The effect of radiation dose. J. Histochem. Cytochem. 20, 425-434 (1972)

Shaw, M.: Cell biological aspects of host parasite relations of obligate fungal parasites. Canad. J. Bot. 45, 1205-1220 (1967)

Slesinski, R. S., Ellingboe, A. H.: Transfer of ${ }^{35} \mathrm{~S}$ from wheat to the powdery mildew fungus with compatible and incompatible parasite/host genotypes. Canad. J. Bot. 49 , $303-310(1971)$

Spurr, A. R.: A low-viscosity epoxy resin embedding medium for electron microscopy. J. Ultrastruct. Res. 26, 31-43 (1969)

Staples, R. C., Ledbetter, M. C. : A study by microautoradiography of the distribution of tritium-labeled glycine in rusted pinto bean leaves. Contr. Boyce Thompson Inst. 19, $349-354(1958)$

Staples, R. C., Ledbetter, M. C.: Incorporation of tritiumlabeled thymidine into nuclei of rusted bean leaves. Boyce Thompson Inst. 20, 349-351 (1960) 